\title{
Health promotion in schools: speeches, representations, and approaches
}

\author{
Promoção da saúde na escola: discursos, representações e abordagens \\ Promoción de la salud en la escuela: discursos, representaciones y enfoques
}

'Universidade Federal de Pernambuco. Vitória de Santo Antão, Pernambuco, Brazil.

"Universidade Federal de Minas Gerais. Belo Horizonte, Minas Gerais, Brazil.

How to cite this article:

Maria Benegelania Pinto' ORCID: 0000-0002-4333-5439

Kênia Lara Silva"

ORCID: 0000-0003-3924-2122

Pinto MB, Silva KL. Health promotion in schools: speeches, representations, and approaches.

Rev Bras Enferm. 2020;73(3):e20180774. doi: http://dx.doi.org/10.1590/0034-7167-2018-0774

Corresponding author: Maria Benegelania Pinto

E-mail: benegelania@yahoo.com.br

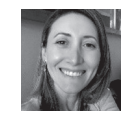

EDITOR IN CHIEF: Antonio José de Almeida Filho ASSOCIATE EDITOR: Hugo Fernandes

Submission: 10-08-2018

Approval: 05-27-2019

\section{ABSTRACT}

Objectives: to analyze speeches, representations, and approaches on health and health promotion in schools, materialized in the speech of teachers. Methods: a qualitative study, of the case study type, carried out with 17 teachers from the municipal and state educational network. The data were obtained from interviews and analyzed by the Content-Oriented Discourse Analysis. Results: medical-sanitary and clinical-biological discourses predominated. Health is represented as the absence of disease, reflecting approaches that prioritize healthy habits and changes in behavior. Problematization of social determinants occurs in projects, in an intersectorial partnership. Final Considerations: carrying out projects of health promotion in schools ignores the solidification of partnerships and the construction of new speeches that represent it as quality of life conditioned by social, economic, and cultural factors as well as strategies for the ideological repositioning of those actors who act in this setting.

Descriptors: Health Promotion; School Health Services; Addresses; Social Determinants of Health; Intersectoral Collaboration.

\section{RESUMO}

Objetivos: analisar os discursos, representações e abordagens sobre saúde e promoção da saúde na escola, materializados na fala de professores. Métodos: estudo qualitativo, do tipo estudo de caso, realizado com 17 professores da rede municipal e estadual de ensino. Os dados foram obtidos de entrevistas e analisados pela Análise de Discurso Textualmente Orientada. Resultados: predominaram os discursos médico-sanitário e clínico-biológico. A saúde é representada como a ausência de doença, repercutindo em abordagens que priorizam hábitos saudáveis e mudanças de comportamento. A problematização dos determinantes sociais ocorre nos projetos, em parceria intersetorial. Considerações Finais: a realização de projetos de promoção da saúde na escola prescinde da solidificação de parcerias e da construção de novos discursos, que a represente como qualidade de vida condicionada por fatores sociais, econômicos e culturais, assim como estratégias para o reposicionamento ideológico daqueles atores que atuam nesse cenário.

Descritores: Promoção da Saúde; Saúde na Escola; Discursos; Determinantes Sociais da Saúde; Colaboração Intersetorial.

\section{RESUMEN}

Objetivos: analizar los discursos, representaciones y enfoques sobre salud y promoción de la salud en la escuela, materializados en el habla de profesores. Métodos: estudio cualitativo, del tipo estudio de caso, realizado con 17 profesores de la red municipal y estadual de enseñanza. Los datos fueron obtenidos de entrevistas y analizados por el Análisis de Discurso Textualmente Orientada. Resultados: predominaron los discursos médico-sanitario y clínico-biológico. La salud se representa como la ausencia de enfermedad, repercutiendo en enfoques que priorizan hábitos saludables y cambios de comportamiento. La problematización de los determinantes sociales ocurre en los proyectos, en sociedad intersectorial. Consideraciones Finales: la realización de proyectos de promoción de la salud en la escuela prescinde de la solidificación de alianzas y de la construcción de nuevos discursos que la represente como calidad de vida condicionada por factores sociales, económicos y culturales, así como estrategias para el reposicionamiento ideológico de aquellos actores que actúan en ese proceso paisaje. Descriptores: Promoción de la Salud; Salud en la Escuela; Discursos; Determinantes Sociales de la Salud; Colaboración Intersectorial. 


\section{INTRODUCTION}

In the world setting, discussion about health promotion was strengthened in international events that launched new proposals in the redefinition of public policies, directing a new look at the health context. As a milestone in this movement, the Ottawa Conference ratifies the idea of health as a quality of life, conditioned by several factors such as peace, housing, education, food, income, stable ecosystem, sustainable resources, social justice, and equity ${ }^{(1-2)}$.

Schools are an important space for health promotion, taking into account the different social actors that compose it, as well as their propensity for subjects-citizens training with great potential for autonomy, participation and social transformation ${ }^{(3)}$. In this perspective, one of the characteristics that makes it compatible with the axes of actions for health promotion is to be able to develop citizen awareness and intervention in the social sphere ${ }^{(4-6)}$.

With regard to health issues, the school has been used for a long time exclusively for the development of preventive activities, with actions directed to the biological model of the clinic, influencing approaches directed at the individual, with vertical methodologies, disciplinary, and disconnected content the socio-political-cultural context ${ }^{(7-8)}$. However, studies reveal an openness to positive changes in relation to determinants and social determinants of health/disease $\mathrm{e}^{(4,9)}$.

Health in schools has advanced in a synchronized way with technical-scientific knowledge and socio-political development, gradually overcoming the biomedical paradigm, especially when it uses approaches that allow an approximation with its actors and problematization of situations demanded by their context ${ }^{(10-11)}$. In this sense, it is affirmed that the discussion about concepts and principles of health promotion have contributed to the sanitary discourse in schools renewal, by opposition to the biomedical model and rescue of the social determination of health/disease, even though these are far from becoming hegemonic ${ }^{(12)}$.

In view of the above, this research was based on the following guiding question: which speeches, discursive representations, and approaches to health and health promotion predominate in school?

\section{OBJECTIVES}

To analyze speeches, representations, and approaches on health and health promotion in schools, materialized in the speech of teachers.

\section{METHODS}

\section{Ethical aspects}

The study complied with the formal requirements contained in Brazilian and international regulatory standards for research involving human beings. The study obtained favorable Opinion 1,913,074, on February 7, 2017.

\section{Theoretical-methodological framework}

The research was based on the Historical and Dialectical Materialism framework ${ }^{(13)}$.

\section{Type of study}

This is a case-study research ${ }^{(14)}$ that used the qualitative approach. The study was developed according to COREQ (for qualitative research).

\section{Methodological procedures}

Seventeen teachers participated, of which 12 were female and aged between 28 and 51 years. Of these, eight were from the state school and nine from the municipal school. The institutional link ranged from six months to 28 years. The initial approximation was through community network meetings, followed by visits to schools. As an inclusion criterion, it was established that participants should present at least six months of professional relationship with the school. Those excluded from work activities for more than 30 days were excluded.

\section{Study setting}

It was carried out in two schools, one state and one municipal, in a neighborhood in the western zone of the municipality of João Pessoa, Paraíba State, Brazil, from February to July 2017. The territory presents areas of social vulnerability, such as riverine communities, high index inequality, and violence, especially due to drug dealing. In the community, there is a community and collective network that promotes and supports actions with educational, health and assistance focus. It is composed of representatives of institutions operating in the territory, including the schools participating in the study. These schools receive actions from the School Health Program (SHP) and projects developed by Non-Governmental Organizations (NGOs) that are part of the local community network.

\section{Collection and organization of data}

The data collection was done through individual semi-structured interviews, viewing the respondents' privacy. To guide the interviews, a script was constructed containing the following questions: How do you perceive health in schools? What and how are health promotion actions developed by the school? In respect to anonymity, an alphanumeric code was used to identify the lines, which shows the initials of each participating school, followed by the number that indicates the order of the interview. Thus, state school representatives were assigned the initials "SSN" and, for the representatives of the municipal school "MSN".

\section{Data analysis}

The analysis was carried out by the Content-Oriented Discourse Analysis (CODA) proposed by Norman Fairclough. Situated in the tradition of qualitative research due to the focus on the detailed analysis of texts and discourses, this analysis turns to the debate of a certain social problem. Thus, there is its contribution to the reflection on the same, differing from other approaches, above all, to allow to present beyond the critical knowledge, the emancipation of subjects of dominant forms through self-reflection ${ }^{(15)}$. 
Critical analysis aims to map connections between choices of social actors or groups, in texts, and specific discursive events. Each person has his unique social practice in which language manifests itself as discourse, that is, as an irreducible part of the ways of acting, interacting, representing and identifying oneself, others and aspects of the world through language. Language is an important resource for the establishment and maintenance of relations of domination and/or for the challenge and overcoming of such problems ${ }^{(16)}$.

Three-dimensional CADO model distinguishes three dimensions of discourse: text, discursive practice, and social practice. Text analysis is detailed in categories of textual analysis, that is, forms and meanings textually associated with ways of representing, interacting and identifying themselves in situated social practices and that help mapping dialectical relations between the discursive and the social, allowing the investigation of characteristic effects of texts in social practice, and vice versa. Discursive practice varies among the different types of discourse, being determined by intricate social factors, production, distribution, and consumption of the text, and analysis of social practice, which is related to the ideological and hegemonic aspects in the analyzed discursive instance ${ }^{(15)}$.

In order to operationalize the analysis, a scheme was constituted by three stages: 1. Data transcription; 2 . Coding and categorization; and 3. Explanatory criticism. The analytical categories identified in the texts reaffirming the naturalized discourses, in the speeches of participants, were value presumption, assessment, modality, and metaphor.

Value presumption concerns the construction of meanings dependent on both what is explicit in the text and what is implied or presumed, the latter being of particular ideological relevance. Assessment is an appreciation or perspective of the speaker, more or less explicit, about aspects of the world and what he considers good or bad, whether he wishes or not. When assessment involves ideological positions, they can act in favor of projects of domination. The modality is associated with an essential semantic trait: polarity, summing up in a personal positioning in the choice between the positive or negative. Finally, metaphor is the structure that shapes identificational meanings in texts, since in selecting such a figure of language in a universe of other possibilities, the speaker understands his reality and identifies it in a particular way ${ }^{(16)}$.

In the analysis, textual fragments were identified that, grouped, conformed three speeches materialized in the speeches of participants: - medical-sanitary discourse, which represents health as absence of disease, whose approach to health promotion is individual and focused on body hygiene actions; - clinicalbiological discourse that represents health as risk prevention and illness, whose approach is grouped and focused on prevention activities, such as lectures on Sexually Transmitted Infections (STIs) and AIDS (Acquired Immunodeficiency Syndrome), vaccination, etc.; - social determinants discourse, which represents health as a quality of life, participation and citizenship, and with a community approach, through activities inside and outside the school focused on citizen training, advocacy, child and youth protagonism, etc. These activities were presented in Charts 1, 2 and 3.

\section{RESULTS}

Chart 1 - Medical-health speech: representation of health as absence of disease. Individual approach and focused on body hygiene actions

\section{Textual fragments (speeches)}

[...] we also give this brushstroke and sometimes there are very serious individual cases on the person's hair hygiene, right? Of dentition ... body and such... [...] MSN 02

[...] so ... I think [laughs] I understand that health promotion is something done daily, that already comes kind of, of [...] let me see [...] hygiene habits, issue that [...] is something that already comes [...] that already comes from, from [...] from home, for example, and that is coming here and we are working on it. I do not know; I think that's it. [laughs] because, thus, the issue of hygiene habits, for example, that is what we usually work in the classroom... [...] MSN 07

[...] ... body hygiene, right? Personal hygiene, right? The main thing that we think, that's where you have to talk more ... right? [...] let's suppose: in this bimester, we choose a week to talk about personal hygiene, body hygiene, personal, there everything we can bring and do, show, present, to catch the attention of the student, we do demonstrations and exhibitions of some things... [...] SSN 04

Chart 2 - Clinical-biological discourse: representation of health as risk prevention and illness. Group approach and focused on prevention activities such as lectures, vaccination, etc.

\section{Textual fragments (speeches)}

[...] there is a partnership with the FHU [Family Health Unit] that makes periodic visits ... weekly, monthly ... and within our planning, as I have already said, we, in transversal themes, for example ... the We work very hard on this too, STIs ... the work on STIs, we have a very intensive work on this part, right?... [...] SSN 01

[...] the subject that most speaks about health is Science and Biology, which studies the human body [...] it always speaks ... about these diseases: HPV [Herpes Papilloma Virus], on the mosquito that transmits to Zica, Dengue, Chikungunya [...] has also been ... for prevention, AIDS as well, HIV [Human Immunodeficiency Virus] [...] SSN 03

[...] It's ... all of a sudden, these people often come from the medical center to do these jobs, right? And there have been lectures, understand? [...] with respect to sexuality, drugs, these things that they need a lot and ... about that, these things that teens need ... and healthy eating have already done work here, including teaching the boys to make the natural sandwich [...] SSN 15

[...] it is the Municipal Education Network [...]You already have it on the calendar so it's important, is not it? Because food is important for health ... we already work within the curricular content [...] the healthy eating week because it already comes in the given calendar... MSN 07

Chart 3 - Social determinants discourse: representation of health as quality of life, participation and citizenship. Community approach, with activities inside and outside the school focused on citizen training, advocacy, child and youth leadership, etc.

\section{Textual fragments (speeches)}

[...] as the goal of the project is to train ... teens, right? For the protagonism ... and for ... to be multiplier agents, right? [...] because it is working with various themes... culture of peace, sexuality, race, and ethnicity. But the project, it comes to contribute because it has reinforced this training, not only with the students, because it also works with professionals in education, school, working with parents and family. I think the work gets more consistent when you do the work with the family, right? With the community [...] MSN 09

To be continued 
Chart 3 (concluded)

\section{Textual fragments (speeches)}

[...] our students participate in the walks, they make tracks along with the teachers, with the theme, and then we go out with them and that walk is here inside the neighborhood itself, understand? Then he joins all the institutions with band, with everything, there goes: with this walk through the stSSNts of the neighborhood, talking about this question of the importance of protecting the child, right? Her childhood, ensuring her childhood with dignity [...] MSN 12

[...] the peace culture project is a development of ... is ... health promotion, I see the work of the NGO [Non-Governmental Organization] and schools, in general, the network itself, right? It's health promotion when you come together to think strategies [...] / see health along with education, along with everything [...] is precisely this guaranteeing basic rights for the community. MSN 17

\section{DISCUSSION}

The representation of health by the actors in Chart 1, translates into the discourse that refers to the hygienist school health model. This model dates back to the beginning of the $20^{\text {th }}$ century, being organized in a context of epidemics, in which discipline was essential in individual and behavioral behavior of students. By postulating health as an absence of disease, without considering the issues of the social context as determinants of this process, participants ratify the paradigm of the medical-sanitary model as hegemonic in their social practices, necessitating new discursive reconfigurations to be overcome ${ }^{(17)}$.

In MSN 02's report, [...] there are very serious individual cases on the person's hair hygiene, right? Of dentition ... body and such. [...], value presumption marks an ideological sense strongly attributed to body care, typical of medical-sanitary discourse. It is accentuated by the absence of elements that could be related to commitment of hygiene of students causes, such as conditions of the social context in which they are inserted. Omission of social determinants reaffirms the representation of illness as an individual burden and the school as a guiding/disciplining space conducive to the adoption of healthy habits/practices.

In the excerpt, [...] The main thing that we think, that's where you have to talk more [...], of SSN 04's report, there is a discursive aspect of assessment that addresses the approach to hygiene practice in schools, which demonstrates a desirable commitment on the part of the participant, with the existence of such an approach in schools.

In addition, hesitation and the modalities, so ... I think ((laughs)) I understand that health promotion is something done daily, that already comes kind of, of [...] let me see [...] hygiene habits, issue that [...] is something that already comes [...] that already comes from, from [...], according to MSN 07 and SSN 04, confirm the point of view and commitment of the speakers with the position of maintaining the logic that holds people personally responsible and individual for health issues, in a link that gives the school the important mission to [...] show, present, to catch the attention of the student [...] for this reality, as expresses SSN 04.

The medical-sanitary discourse, articulated in the reports of the representatives of the schools, shows how this trend is still reproduced today, despite the conceptual and methodological changes that have incorporated the concept of public health promotion in recent decades ${ }^{(1,2)}$.
By maintaining and reproducing hygienic practices in approaching health issues, the school reaffirms itself as an apparatus for the maintenance of hegemonies, such as knowledge and practices based exclusively on clinical and biological ${ }^{(4)}$, which constitute an element of contradiction in the health approaches in schools. Schools should be a space for the problematization of social determinants, starting from the questions related to the local reality and produced by the complex problems of their surroundings, to print the redefinition of new conceptions and knowledge used to the transformation of realities ${ }^{(3)}$.

Schools as an environment conducive to health promotion, goes through the understanding of this space as a potential for the discussion of social determinants. In this context, in the context of Latin America and the Caribbean, the Health Promoting Schools Regional Initiative, officially launched in 1995, is highlighted by the Pan American Health Organization and the World Health Organization Regional Office ${ }^{(5-6)}$.

Health Promoting Schools serve the interfaces of school with society and commitment to the living conditions of the populations. From this point of view, health promotion in schools comprises three main components: health education with a comprehensive approach; creation of healthy environments; and provision of health services ${ }^{(6)}$.

Brazil has strengthened its actions to promote health in schools, reviewing the activities developed in the field of school health, through the articulation of the education, health and society sectors, with emphasis on the protagonist action of the school community in identifying needs, problems strategies to address and address them ${ }^{(5)}$.

In order to approach health, in an extended perspective, which considers the social determinants, as recommended in the Ottawa Charter, the Brazilian Unified Health System (SUS Sistema Único de Saúde) and the National Curriculum Parameters (PCN - Parâmetros Curriculares Nacionais), school professionals, especially teachers, need to reflect on their practice in a selfreflexive movement that allows denaturalizing old reductionist conceptions. These conceptions reproduce ways of thinking about health issues, disjointed from the real conditions that determine them. They also need to adopt inclusive and participative educational approaches, necessary for the integrated construction of knowledge in a citizen perspective ${ }^{(1,18)}$.

In this context, the school has a basic political role. It is the setting that favors deconstruction of old paradigms, as well as construction of discourses by incorporating new knowledge, either through transmission of values and beliefs, or because nature, essentially educational, serve as an environment conducive to the development of actions that build and solidify not only habits but, above all, attitudes with transformative potential ${ }^{(3)}$.

Approach of health issues in school has been carried out especially from the point of view of the control and prevention of illness, and of situations of risk and health problems, from a perspective of epidemiological surveillance and clinical-therapeutic assistance. With this, there is the ideological valorization of scientific knowledge as hegemonic practice ${ }^{(17)}$.

Health representation, in the logic of risk prevention and sickness, in Chart 2, favors approaches whose focus is group, with actions directed mainly to the public of adolescents with clinical-biological discourse. In the latter perspective, most SHP activities, such as 
vaccination, lectures given by health professionals on STIs, teenage pregnancy and drugs, as well as projects related to the Healthy Eating Week, are aimed at favoring of healthy habits and behavior change.

It is not surprising that health-related contents, integrated into the curriculum, are attributed as a responsibility of the components Science and Biology, disciplines that bring students closer to health issues, exclusively in the biological and pathological logic, reaffirming the hegemony of this field of know about others ${ }^{(16)}$. According to SSN 03, [...] the subject that most speaks about health is Science and Biology, which studies the human body [...] it always speaks ... about these diseases: HPV (Herpes Papilloma Virus), on the mosquito that transmits to Zica, Dengue, Chikungunya [...] has also been ... for prevention, AIDS as well, HIV (Human Immunodeficiency Virus) [...].

Issues related to health education, which are not problematized or solved by the school, tend to have, as only alternative, health services, with the expectation of solving them from a medical perspective. On the other hand, the multicausality of health-disease requires the need to consider the complexity of the social determinants of health, which requires coping strategies that require broad actions capable of articulating diverse sectors for successful enterprises ${ }^{(17)}$.

SHP, in its intersectoral proposal, should operate a health approach in the school, in the perspective of an articulated work between education, health and society, with an expectation of overcoming the hygienist school health paradigm ${ }^{(5)}$. Nonetheless, the results of this study allow us to affirm that there is an established contradiction in participants' social practices, in which the actions of reinforcing the preventivist and therapeutic aspects as priorities in the school activities agenda are observed, including those in partnership with health unit.

These practices still serve as a marker for health approaches in the school environment, when they should have already been overcome. Silencing social determinants, in the speeches of participants, signs interdiscourse that articulates the hegemonic discourses of biomedicine and school hygiene. On the other hand, the expanded perception of health considers the living conditions of people as an indispensable factor for the quality of life $\mathrm{e}^{(9)}$.

In this struggles of knowledge and expertise arena, one speaks from the position that is taken in the ideological struggle. In treating the situation of mosquito-borne diseases, STIs and teenage pregnancy as permanent and natural situations, teachers make use of one of the modes of operation of ideology, reification. Reification is used by the strategies of symbolic construction of nominalization/passivation, which lends focus to certain naturalized topics in the subjects' speeches, so that there is prejudice to those that were not put to discussion, which, in most cases, are the determinants of the problem situations existing in the context and surroundings of schools ${ }^{(16)}$.

This assertion is confirmed in the statements that omit the historical, social and cultural determination that produce the conditions that favor the proliferation of mosquitoes, such as the lack of public policies and adequate sanitation, income distribution, among others, erasing the responsibility of the State with these issues. On the other hand, it is evident the exclusive responsibility of the community in maintaining its healthy environment.

In the same logic, STIs and teenage pregnancy, when addressed without considering cultural and social factors, such as income distribution, access to quality health services, lack of investment in actions that value and motivate youth to construction of life projects, it is emphasized the responsibility of this problem exclusively for adolescents.

Valuation presumption is also identified in the same report, when referring to the intense work involved in the elimination of the Dengue mosquito and prevention of STIs, according to the excerpt, [...] STIs ... the work on STIs, we have a very intensive work on this part, right? [...]. There are also propositional presumptions in the excerpt, they need a lot and ... about that, these things that teens need...[...], which serve the representation of the school as an important element to confront these problems.

Moreover, it is possible to identify the presence of the category of assessment, in the excerpt, [...] it is the Municipal Education Network [...] you already have it on the calendar so it's important, is not it? Because food is important for health...[...], of MSN 07's speech, when referring to the healthy eating week as a curricular activity in the school. Assessment, in this setting, concerns the speaker's perspective on what he considers to be good, in this case, what is determined by the municipal body, leaving implicit its ideological position, in favor of projects focused on individual responsibility of students and detached from their social context ${ }^{(16)}$.

In this situation, it is possible to relate an ideological-hegemonic position in the discourse, omitting social and cultural conditions that influence and determine the eating habits of these people. This positioning is revealed by attributing value to the importance of adopting healthy eating habits and referring to the Municipal Education Network as the one that decides on the integration of this activity into the school curriculum.

Discourses and practices that "aim to delegate more and more to specific social groups and individuals the task of caring for themselves" would be satisfactory if there were no side effect of the state's lack of responsibility, regarding the conditions for this care to be considered, in fact, the subjects' choices $^{(19)}$.

Despite the existence of a hygienist and preventivist logic in the health education trajectory, with the presence of normative components and predefined contents on what should be done and discussed in health in schools, other meanings have emerged and consolidated in line with the principles health promotion ${ }^{(17)}$. Thus, educational practices related to criticism of reality, based on local problems, with emphasis on the training of autonomous subjects capable of participating and exercising control of health and life conditions, have occurred in the context of schools, although incipient ${ }^{(8)}$.

Nonetheless, in the context studied, in isolation, the school seems unable to mobilize to address issues related to healthdisease determinants, considering the complex problems that exist in its surroundings, which are reflected in its conjuncture, such as social inequalities, violence, etc.

The findings of this study indicate that the approach to social determinants occurs when there are partnerships with NGOs, through projects developed in schools, supported by the local community network, according to the statements presented in Chart 3. It reaffirms, thus, the intersectoriality as indispensable in the renewal of collective health practices ${ }^{(20)}$.

In this logic, more focused actions in the context of schools, such as the "Tecendo uma Cultura de Paz" project and walks that take place in the neighborhood in reference to peace and the fight against the sexual exploitation of children and adolescents, carried 
out in partnership with the Network, seem to present themselves as an alternative to the hegemonic models of school hygiene and clinical practice. This is because they bring themes related to the social determinants in their portfolio and they turn not only to students, but also to families, school professionals, and community.

Another aspect perceived, with the incorporation of these projects in the school, is the intention to train local protagonists, with a view to favoring future leaderships in the community, leading to participation, an important condition for the construction of the subjects' autonomy, to a democratic perspective.

The incorporation of practices that prioritize discussion of social determinants brings the actors of the school closer to the complex issues of the environment, which are reflected in their daily life and allows the problematization and criticism of the difficulties resulting from the relations of domination and absences of the State. The self-reflection generated from this debate can become the engine for the production of new discourses, essential to the social transformation characteristic of a phenomenon in movement, in the dialectical perspective.

Discourse plays an important role in social change, because it allows production, reproduction, and overcoming of inequalities and domination relations, since we speak what is practiced and vice versa. Discursive change, in this sense, implies social transformation, given the dialectical relationship between the two dimensions of change ${ }^{(16)}$.

Thus, hegemonic discourses of hygiene and the clinic maintenance in schools confronts its potential for generating reflection and action for the transformation of realities. Nevertheless, the partnership with the Network emerges as a viable intersectoral proposal, for adding to the complex issues facing the territory and making feasible, among other points, the construction of new discourses that represent health as a guarantee of rights and quality of life. Nevertheless, the phenomenon is in transformation and, in this process, provisional syntheses are produced that allow accumulation until the qualitative change.

\section{Study limitations}

This study presents as a limitation the fact of being a site cut. Larger studies are desirable and include settings in more diverse realities.

\section{Contributions to Nursing, Health, and Public Policy}

The study may contribute to the reflection-action (praxis) of professionals of education and health sectors, regarding the practices of health promotion in schools, collaborating with the overcoming of the hegemonic model in force in this setting.

\section{FINAL CONSIDERATIONS}

Medical-sanitary and clinical-biological discourses hegemony in the social practice of teachers represents health as absence of disease. It dissociates health from social issues and assigns individual responsibility for illness, determining an approach to health promotion from the perspective of risk prevention, with actions focused on behavior change, with the need to be overcome. The projects supported by the local community network reveal themselves as initiatives that allow the problematization of social determinants of health and disease, favoring the construction of new discursive representations about school as a space for citizen building.

Therefore, taking health promotion projects to school does not result in the solidification of partnerships with the various sectors and community; the construction of new discourses that represent health as a project of citizenship and quality of life; the revision of approaches to health promotion in schools, as well as strategies for ideological repositioning of those actors of this setting, especially teachers.

The teacher stands out because he is an important articulator and multiplier of new concepts and ideas, which require to its incorporation, educational approaches that allow critical reflection and participation, indispensable tools for the shared construction of knowledge used to solve local problems and generation of changes.

\section{FUNDING}

A special thanks to the Coordination for the Improvement of Higher Education Personnel (CAPES - Coordenação de Aperfeiçoamento de Pessoal de Nível Superior) for financing the Interinstitutional Doctorate and granting a scholarship during the probationary period in the city of Belo Horizonte.

\section{REFERENCES}

1. Malta CD, Neto OLM, Silva AM, Dais MR, Castro AM, Reis AAC, Akerman M. National Health Promotion Policy (PNPS): chapters of a journey still under construction. Ciênc Saúde Colet. 2016;21(6):1683-94. doi: 10.1590/1413-81232015216.07572016

2. López-Fernández LA, Hormazábal OS. Repensar la Carta de Ottawa 30 años después. Gac Sanit. 2017;31(6):443-5. doi: 10.1016/j. gaceta.2016.12.013

3. Mont'Alverne DGB, Catrib AMF. Promoção da saúde e as escolas: como avançar. Rev Bras Promoç Saúde. 2013;26(3):307-8. doi: 10.5020/18061230.2013.p307

4. Vieira AG, Aerts DRGC, Câmara S, Schubert C, Gedrat DC, Alves GG. A escola enquanto espaço produtor da saúde de seus alunos. Rev Ibero-Americana Est Educ [Internet]. 2017 [cited 2018 Jul 27];12(2):916-32. Available from: https://periodicos.fclar.unesp.br/iberoamericana/ article/view/8492

5. Ministério da Saúde (BR). Departamento de Atenção Básica. Passo a passo PSE. Programa Saúde na Escola: tecendo caminhos da intersetorialidade [Internet]. Brasília: Ministério da Saúde; 2011 [cited 2018 July 27]. Available from: http://bvsms.saude.gov.br/bvs/ 
publicacoes/passo_a_passo_programa_saude_escola.pdf

6. Organização Panamericana de Saúde (OPAS). Escolas promotoras da saúde: fortalecimento da iniciativa regional: estratégias e linhas de ação 2003-2012. Washington: OPAS; 2012.

7. Casemiro JP, Fonseca ABC, Secco FVM. Promover saúde na escola: reflexões a partir de uma revisão sobre saúde escolar na América Latina. Ciênc Saúde Colet. 2014;19(3):829-40. doi: 10.1590/1413-81232014193.00442013

8. Moraes MCL. Promoção da saúde: visitando conceitos e ideias. REFACS. 2017;5(1):75-9. doi: 10.18554/refacs.v5i1.1917

9. Lima-Serrano M, Lima-Rodríguez JS. Impact of school-based health promotion interventions aimed at different behavioral domains: a systematic review. Gac Sanit Gac Sanit. 2014;28(5):411-7. doi: 10.1016/j.gaceta.2014.05.003

10. Graciano AMC, Cardoso NMM, Mattos FF, Gomes VE, Borges-Oliveira AC. Promoção da Saúde na Escola: história e perspectivas. J Health Biol Sci. 2015;3(1):34-8. doi: 10.12622/2317-3076jhbs.v3i1.110p.34.2015

11. Carvalho FFB. A saúde vai à escola: a promoção da saúde em práticas pedagógica. Physis. 2015;25(4):1207-27. doi: 10.1590/ S0103-73312015000400009

12. Silva-Arioli IG. Promoção e educação em saúde: uma análise epistemológica. Psicol Ciênc. Prof. 2013;33(3):672-87. doi: 10.1590/ S1414-98932013000300012

13. Cheptulin A. A dialética materialista: categoria e leis da dialética. $2^{\text {a }}$ ed. São Paulo: Alfa-Ômega; 2004.

14. Yin RK. Estudo de caso: planejamento e métodos. 5a ed. Porto Alegre: Bookman; 2014

15. Fairclough N. Discurso e mudança social. 2a ed. Brasília: Editora da UNB; 2016.

16. Vieira V, Resende, VM. Análise de discurso (para a) crítica: o texto como material de pesquisa. 2a ed. Campinas: Pontes; 2016.

17. Silva CS, Bodstein, RCA. Referencial teórico sobre práticas intersetoriais em Promoção da Saúde na escola. Ciênc Saúde Colet. 2016:21(6):1777-88. doi: 10.1590/1413-81232015216.08522016

18. Câmara dos Deputados (BR). Lei no 13.005, de 25 de junho de 2014. Aprova o Plano Nacional de Educação (PNE) e dá outras providências [Internet]. Brasília: Câmara dos Deputados; 2015 [cited 2018 Jul 27]. Available from: https://www2.camara.leg.br/legin/fed/lei/2014/lei13005-25-junho-2014-778970-publicacaooriginal-144468-pl.html

19. Mendes R, Fernandez JCA, Sacardo DP. Promoção da saúde e participação: abordagens e indagações. Saúde Debate. 2016;40(108):190-203. doi: 10.1590/0103-1104-20161080016

20. Moysés ST, Sá RF. Planos locais de promoção da saúde: intersetorialidade(s) construída(s) no território. Ciênc Saúde Colet. 2014;19(11):43239. 10.1590/1413-812320141911.11102014 